\title{
OCCUPATIONAL EXPOSURE TO PESTICIDES AND KNOWLEDGE ABOUT RELATED POLICIES IN URBAN PEST CONTROL OPERATORS FROM SOUTHEAST MEXICO
}

\author{
Karla Denisse RUIZ-GAMBOA ${ }^{1}$, Rúben Marcelo CÁMARA-VALLEJO², \\ Manuel René MEDINA-MORENO², Nelly Eugenia ALBERTOS-ALPUCHE ${ }^{2}$, \\ Ramón Ignacio ESPERÓN-HERNÁNDEZ², Rita Esther ZAPATA-VÁZQUEZ², \\ Aurora Elizabeth ROJAS-GARCÍA ${ }^{3}$, Irma Martha MEDINA-DÍAZ ${ }^{3}$, Gabriel Ángel MONTERO-LARA ${ }^{4}$, \\ José Cupertino MOO-HUCHIN ${ }^{4}$, Angel SILVA-PÉREZ ${ }^{5}$ and Norma Elena PÉREZ-HERRERA ${ }^{2 *}$
}

\footnotetext{
${ }^{1}$ Maestria en Investigación en Salud, Posgrado Institucional en Ciencias de la Salud, Universidad Autónoma de Yucatán

${ }^{2}$ Cuerpo Académico de Salud Pública, Facultad de Medicina, Universidad Autónoma de Yucatán

${ }^{3}$ Laboratorio de Contaminación y Toxicología Ambiental, Secretaría de Investigación y Posgrado, Universidad Autónoma de Nayarit

${ }^{4}$ Laboratorio de Analisis Clínicos, Facultad de Química, Universidad Autónoma de Yucatán

*Author for correspondence: norma.perez@correo.uady.mx
}

(Received January 2017; accepted March 2018)

Key words: regulation, urban pest control operator, butyrylcholinesterase activity

\begin{abstract}
Pesticides, which are widely used in tropical areas for controlling disease vectors, require the services of urban pest control operators (fumigators). Pesticide use and handling policies and regulations mostly relate to agricultural uses, not to urban pest control purposes. Our objectives included investigating use patterns, pesticide management practices, knowledge on related policies in urban pesticide applicators of southeastern Mexico, and comparing butyrylcholinesterase (BuChE) activity in this group with individuals non-occupationally exposed to pesticides. We conducted a cross-sectional study where all participants were males. The exposed group was integrated by 27 urban pest control operators and the non-exposed group by 26 non-sprayer subjects. A structured questionnaire was applied to participants and BuChE activity in serum was determined. Urban pest control operators had been working with pesticides for 1-17 years, mostly during summer; $67 \%$ did not use personal protection equipment. Eighteen active ingredients were employed as pesticides; chemical groups included pyrethroids (PYR), organophosphates (OP), coumarins, phenylpyrazoles, carbamates (CAR), chloronicotinyls, and amides. Policy knowledge and application were reported in only $30 \%$ of the fumigators. BuChE activity (U/L) was similar between groups: $9837.95 \pm 1844.46 \mathrm{U} / \mathrm{L}$ in urban pest control vs. $10414.81 \pm 1558.42 \mathrm{U} / \mathrm{L}$ for the non-sprayer group. We suggest the inclusion of additional biomarkers in the evaluation of occupational exposure to pesticides, because currently only OPs and CARs are considered, while fumigators are exposed to many other pesticides. Urban pesticide applicators lacked knowledge regarding pesticide management and application policies, hence the need for educational courses for workers and updating regulations.
\end{abstract}

Palabras clave: regulaciones, fumigadores urbanos, actividad de butirilcolinesterasa 


\section{RESUMEN}

Los plaguicidas son ampliamente utilizados en zonas tropicales para el control de vectores de enfermedades, por tanto se requiere el servicio de aplicadores urbanos (fumigadores). Las políticas y regulaciones para el uso y manejo de plaguicidas están principalmente relacionadas con su uso agrícola y no con su empleo para el control de plagas urbanas. Nuestro objetivo fue conocer los patrones de su uso, las prácticas para el manejo de plaguicidas y el conocimiento de las políticas relacionadas por parte de aplicadores urbanos del sureste de México. Se realizó un estudio transversal en el que el grupo expuesto estuvo integrado por 27 aplicadores y el grupo no expuesto por 26 sujetos sin exposición ocupacional a plaguicidas. Se aplicó un cuestionario estructurado a los participantes y se determinó la actividad de butirilcolinesterasa (BuChE, por sus siglas en inglés). Los sujetos del grupo expuesto habían trabajado de 1 a 17 años como fumigadores, mayormente durante el verano, y $67 \%$ no utilizó equipo de protección personal durante sus actividades. Se utilizó un total de 18 ingredientes activos como plaguicidas, de los siguientes grupos: piretroides (PYR), organofosforados (OP), cumarinas, fenilpirazoles, carbamatos (CAR), cloronicotinilos y amidas. El conocimiento y aplicación de políticas se reportó sólo en $30 \%$ de los fumigadores urbanos. La actividad de BuChE fue similar entre grupos (9837.95 $\pm 1844.46 \mathrm{U} / \mathrm{L}$ en fumigadores y $10414.81 \pm 1558.42 \mathrm{U} / \mathrm{L}$ en sujetos no expuestos). Se sugiere la inclusión de marcadores biológicos adicionales en la evaluación de la exposición ocupacional a plaguicidas, dado que los actuales sólo consideran la presencia de OP y CAR, pero los aplicadores están expuestos a otros tipos de plaguicidas. Se concluye que se requiere educar a los trabajadores y actualizar la regulación existente.

\section{INTRODUCTION}

Environmental pollution has always existed, as it is inherent to human activities. However, in recent years the topic has received increasing attention because the frequency and severity of pollution problems have increased worldwide, and there is growing evidence of its adverse effects on the environment and public health. As a result, international treaties, conventions, and agreements have been established to regulate and control the use of many contaminating substances, including pesticides (Albert 2004). However, in developing countries like Mexico, observing the regulations on pesticides represents a challenge due to social, political, and economic issues (Romero-Lankao 1999). Mexico takes part in several conventions that deal with problems generated by the presence of toxic residues, including the Stockholm Convention on Persistent Organic Pollutants, the Rotterdam Convention, the Basel Convention, the Montreal Protocol, and the International Code of Conduct on the Distribution and Use of Pesticides. The documents emerging from these conventions aim towards the regulation of the trade and use of hazardous products. Nationwide, formulation activities, manufacturing, application, and trading of pesticides are regulated by the Comisión Intersecretarial para el Control del Proceso y Uso de Plaguicidas y Sustancias Tóxicas (Inter-Secretariat Commission for the Control of Processes and Use of Pesticides, Fertilizers, and Toxic Substances, CICOPLAFEST), comprising institutions such as COFEPRIS, SEMARNAT, SAGARPA, SS, and STPS (Cortinas 2004). However, these institutions only regulate the use of pesticides for agricultural purposes, but their urban application is not clearly defined.

Pesticides in urban areas are utilized for plague control or for public health programs. They have contributed to the control of vector-borne diseases such as dengue, chikungunya, zika, rickettsiosis, and Chagas disease, among others, which are highly prevalent in southeastern Mexico due to climatic factors. In the period between 2015 and 2016, Yucatan was the eighth highest state in cases of dengue (9946 probable and 841 confirmed) (SSA 2015). Fumigation programs have increased due to this outbreak; as a result, the use of pesticides has also expanded. In contrast, to our knowledge, no new laws or regulations have been issued on pesticides for urban use, as would be expected in response to their growing use (Cortinas 2004). When pest control programs do not cover the demand, urban pest-control companies are used. An urban pest control operator (UPCO) is a professional - often a private operator - who carries out control of nuisance pests and other pests of public health importance at the request of a client, for example in and around the houses, offices, warehouse, stockroom, storage and hospitals (FDA 2009). 
Appropriate use of pesticides requires considering good practices and integrated pest control, which allows reducing risks for human health and the environment (OMS 1990). Simultaneously, the rise in the use of pesticides has led to an increase in intoxications and associated diseases. Accordingly to data gathered by the World Health Organization (WHO), each year approximately two million persons become intoxicated with pesticides, and between 2000 and 5000 of these die. At least $50 \%$ of the intoxicated individuals and $75 \%$ of those who die are farm workers (Eddleston et al. 2002).

The effects of pesticides in an exposed population depend on the type of molecule, dose, and route and time of exposure, as well as individual susceptibility. Little is known about the exposure scenario of urban pest control operators (fumigators); Aldana et al. (2003) observed significant differences in semen liquefaction time, viscosity, and motility, as well as reduced viability and low sperm concentration in urban applicators from northern Mexico with respect to the control group. Additionally, Mendívil et al. (2004) found alterations in sperm motility, viability, and concentration in pest control workers of Sonora, Mexico.

In Mexico, 260 brands of pesticides are in use: 34 of these are banned and 13 are restricted; moreover, among the 90 pesticide types banned in the USA, 30 are being produced in Mexico. González-Arias et al. (2010) reported that the most used and sold pesticides in Nayarit are organophosphates (OP), followed by pirethroids (PYR), carbamates (CAR), and organochlorines (OCP); among these, we can find pentachlorophenol, which is prohibited in Mexico due to its extreme toxicity (INIFAP 2011).

In Yucatan, there have been reports of adverse effects related with pesticide exposure on public health in agricultural-based communities. Among the effects related to exposure, we can find acute intoxications and chronic effects such as respiratory failure, bronchorrhea, altered enzymatic activities, delayed neuropathies, altered sperm morphology, genotoxic effects, DNA fragmentation, and an increase in abortion frequency in the sprayers' wives (González et al. 1996, González y Alvarado 2008, Pérez-Herrera et al. 2008).

To our knowledge, no report has been published in Mexico on the fumigators' knowledge about pesticide policies in urban areas (indoor or outdoor), nor on the health impact of pesticides on their users. To date, pesticide usage patterns in urban areas are poorly studied. This study is, to our knowledge, the first to show the scenario of occupational exposure to urban pesticides in Yucatan. Our objectives were to investigate use patterns, pesticide management practices, and knowledge on related policies in a group of urban pest control operators in southeastern Mexico, and to compare the activity of butyrylcholinesterase $(\mathrm{BuChE})$ in this group with respect to a group of subjects non-occupationally exposed to pesticides.

\section{Study area}

\section{METHODS}

We conducted this study in the city of Merida, the Yucatan state capital, located in southeastern Mexico (Figure 1). It is an area considered as endemic for the transmission of dengue, chikungunya, and zika viruses (SSA 2015); its weather is hot and humid, with an average yearly temperature of $26^{\circ} \mathrm{C}$ and average annual precipitation of $1100 \mathrm{~mm}$. Its geographic coordinates are: $21^{\circ} 36^{\prime}-19^{\circ} 32^{\prime} \mathrm{N}, 87^{\circ} 32^{\prime}-90^{\circ} 25^{\prime} \mathrm{W}$ (INEGI 2016).

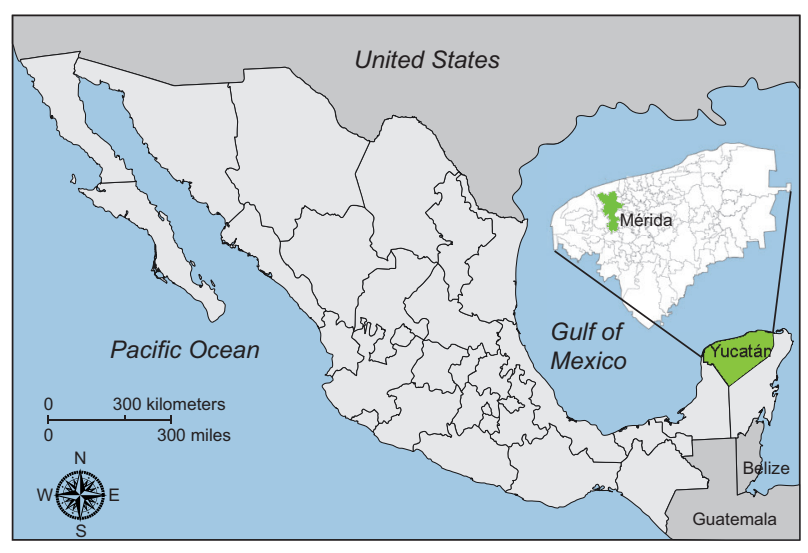

Fig. 1. Map of Mexico with the state of Yucatán highlighted in green. Merida is its capital

\section{Study population}

The target population was urban pest control operators from the city of Merida, who were occupationally exposed to pesticides for at least one year. We contacted study subjects by telephone (through numbers for pest control companies appearing listed in the telephone directory of Merida ) and by means of study promotion and personal invitations at meetings held at the local urban pest-control companies' association. The urban pest control operators participated voluntarily in the study.

\section{Structured survey}

We applied a survey to urban pest control operators and to the group non-occupationally exposed 
to pesticides. The survey comprised working conditions, pattern of exposure to pesticides, and knowledge concerning policies related to pesticides.

\section{BuChE activity determination}

Urban pest control operators and control group subjects donated a blood sample for BuChE determination. The blood was centrifuged and an aliquot of plasma was used for BuChE determination using the ChE Gen 2 kit (PN 04498577190, Roche Diagnostics) on the COBAS INTEGRA 800 analyzer according to the manufacturer instructions. Precision was determined using internal controls. The lower detection limit is reported as $100 \mathrm{U} / \mathrm{L}$. BuChE activity was reported in $\mathrm{U} / \mathrm{L}$.

\section{Ethical considerations}

The Ethical Committee Board of the Faculty of Medicine of the Autonomous University of Yucatan approved the current project, whose development complied with ethical guidelines in order to guarantee the dignity and well-being of volunteers, and it adhered to the principles established in the Nuremberg Code and the Declaration of Helsinki.

\section{Statistical analysis}

The obtained data were entered into a database generated with statistical software programs Stata v. 12.1 and EpiInfo v. 3.3.2. Quantitative values and frequency distribution for the qualitative variables corresponding to each parameter were evaluated. We employed Student $t$-test to compare BuChE activity between study groups, considering a value of $p<$ 0.05 as statistically significant.

\section{RESULTS AND DISCUSSION}

\section{Characteristics of urban pest control operators}

The general characteristics of the study participants are presented in table I. The average age of the pesticide worker was 35 years, which is a reproductive age (range, $19-55$ years) and $74 \%$ of these were married. Age was similar to that of other studies carried out in fumigators and farmers (Hines et al. 2001, Pérez-Herrera et al. 2008, Rojas-García et al. 2011, Silveira et al. 2011).

It has been described that environmental and occupational exposure to pesticides produces severe reproductive problems and affects the quality of semen, causing a decrease in the volume of the ejaculate, in sperm motility, and in the percentage of spermatozoa with normal morphology in urban
TABLE I. GENERAL CHARACTERISTICS OF THE STUDY POPULATION

\begin{tabular}{lc}
\hline Characteristics & Urban pest control operator (\%) \\
\hline Age (years) $)^{\mathrm{a}}$ & $35(19-55)$ \\
Education level & 4 \\
No education & 7 \\
$\quad$ Elementary education & 7 \\
$\quad$ Middle school & 60 \\
$\quad$ High school & 22 \\
$\quad$ Post-secondary education & 0 \\
Postgraduate & 7 \\
Montly income & 7 \\
$\quad<2000 \mathrm{MXN}$ & 41 \\
$\quad$ 2000-4000 MXN & 45 \\
$\quad 4000-10000 \mathrm{MXN}$ & $29.17 \pm 3.88$ \\
$\quad>10000 \mathrm{MXN}$ & $82.35 \pm 11.72$ \\
Body mass index $\left(\mathrm{kg} / \mathrm{m}^{2}\right)^{\mathrm{b}}$ & 58 \\
Weight $(\mathrm{kg})^{\mathrm{b}}$ & 63 \\
Smokers & \\
Acohol consumption & \\
\hline
\end{tabular}

${ }^{\mathrm{a}}$ Median (range); ${ }^{\mathrm{b}}$ arithmetic mean $\pm \mathrm{SD}$

pest-control workers and in farmers; the fertility of sprayers can be compromised (Aldana et al. 2003, Mendivil et al. 2004, Pérez-Herrera et al. 2008). In addition, $78 \%$ of these subjects have overweight problems. Obesity in adults in Yucatan state ranks first at the national level and comprises the main risk factor for the development of chronic diseases such as diabetes mellitus and cardiovascular diseases (INSP 2013). Both the group of applicators and the group of subjects non-occupationally exposed to pesticides had the same percentage of overweight problems (data not shown).

\section{Working conditions}

The working conditions of urban pest control operators are shown in table II. The participants had an average of four years working as fumigators, and $37 \%$ had more than five years in such employment. Studies describing the working conditions of urban pest control operators are scarce. A study conducted in northern Mexico by Silveira et al. (2011) showed that the average working time as sprayers was 6.83 years, observing a relationship between the years of work as a sprayer and the presence of pesticide residues in biological samples.

These authors state that the exposure of urban sprayers to pesticides is more intensive because they are subject to long daily periods of exposure throughout the year. A regular workday for the study population was $8 \mathrm{~h} /$ day, 6 days/week, with a spraying lapse 
TABLE II. WORKING CONDITIONS OF URBAN PEST CONTROL OPERATORS

\begin{tabular}{|c|c|}
\hline Characteristics & $\begin{array}{l}\text { Urban pest control } \\
\text { operators }(\%)\end{array}$ \\
\hline Years working as a urban pest control operators ${ }^{a}$ & $4(1-17)$ \\
\hline $1-5$ years & 63 \\
\hline $6-10$ years & 22 \\
\hline$>10$ years & 15 \\
\hline \multicolumn{2}{|l|}{ Work done in the company } \\
\hline Operator & 77 \\
\hline Property owner & 23 \\
\hline Social security by the company (yes) & 56 \\
\hline Days of vacation in the year ${ }^{\mathrm{a}}$ & $7(3-15)$ \\
\hline While remaining within the company (hours) ${ }^{\mathrm{a}}$ & $8(4-18)$ \\
\hline \multicolumn{2}{|l|}{ Frequency of spraying: } \\
\hline Hours a day ${ }^{\mathrm{a}}$ & $4(1-14)$ \\
\hline Days of the week ${ }^{\mathrm{a}}$ & $6(3-7)$ \\
\hline \multicolumn{2}{|l|}{ Main season of spraying: } \\
\hline Summer & 80 \\
\hline Winter & 12 \\
\hline Spring & 4 \\
\hline Autumn & 4 \\
\hline \multicolumn{2}{|l|}{ Places often fumigated: } \\
\hline Nightclubs & 23 \\
\hline Parks & 15 \\
\hline Gardens & 15 \\
\hline Houses & 15 \\
\hline Industries & 12 \\
\hline Restaurants & 12 \\
\hline Schools & 8 \\
\hline \multicolumn{2}{|l|}{ Informative talks on pesticides } \\
\hline Kind of informative talks on pesticides & 100 \\
\hline Use the pesticide according to the plague & 74 \\
\hline Types of pests & 44 \\
\hline Personal protection equipment & 41 \\
\hline \multicolumn{2}{|l|}{ Knowledge on safety use of pesticides } \\
\hline Pesticide poisoning & 63 \\
\hline Colors of the pesticide labels (toxicity) & 44 \\
\hline Routes of entry of pesticides into the body & 4 \\
\hline What are pyrethroids? & 85 \\
\hline What are organophosphates? & 74 \\
\hline What are carbamates? & 70 \\
\hline What are organochlorines? & 52 \\
\hline
\end{tabular}

${ }^{a}$ Median (range)

of $4 \mathrm{~h}$ /day (Silveira et al. 2011). Yeary et al. (2009) conducted a several years-long review with workers whose main occupation was applying fertilizers and pesticides in urban areas; the workers reported working 50-60 h/week; one third of that time was spent in spraying. Kamijima et al. (2004) reported that, for Japanese sprayers, summer is the period during which spraying is most requested, similar to that reported by Garry et al. (2003) in Minnesota and Pérez-Herrera et al. (2008) in southeastern Mexico.
This scenario is in agreement with our study results; summer was the most intense period of the year for spraying services.

Among urban pest control operators, $23 \%$ are the owners of a company in addition to their work as fumigators; $56 \%$ have access to medical services by the company. All of the urban pest control operators attended at least one talk regarding the handling of pesticides provided by a pesticide-sales company. Most fumigators possessed some information about 
the types of pesticides, plagues, and technical issues: six out of ten urban pest control operators knew that pesticides are dangerous to health, but they were unacquainted with routes of exposure, and four out of 10 knew about the color code for hazard identification. Arcury et al. (2002) asserted that Mexican agriculturists lack sufficient training on the use and handling of pesticides and the manner in which this deficiency is related with their perception of risks. The Official Mexican Standard NOM-256-SS1-2012 (SSA 2013) establishes the sanitary conditions that organizations and all personnel related with pests control must observe. It emphasizes that pesticide workers must not be involved in administrative tasks; in addition, the owner or manager of such organizations must provide the workers with training and give them talks about the risks of the profession.

\section{Pattern of exposure to pesticides}

Table III depicts the most frequent insecticides used by urban pest control operators, who are exposed to a mix of pesticides. We identified 18 active ingredients utilized as pesticides, with $94 \%$ of these presenting moderate-to-extreme toxicity. With respect to classification by chemical group, 33 $\%$ of the active ingredients include PYR; OP and coumarins represent $17 \%$ each, and $11 \%$ are CAR. Of the pesticides, $78 \%$ were insecticides, which are the most employed pesticides at any time of the year, followed by rodenticides. The latter are mostly used in the spring and summer, and herbicides in autumn and winter.

Long-term use of pesticides has the following repercussions on the health of exposed individuals: damage to the neurological and reproductive systems; liver disease; hormonal alterations, and cancer, among others (Albert 2004, Mostafalou and Abdollahi 2017). The main effects of the 18 pesticides reported in this study on health are the following: neurotoxic (39\%); genotoxic (33\%); carcinogenic (33\%); endocrine disruptors ( $22 \%)$, and alterations in semen quality ( $6 \%)$. There are, to our knowledge, no conclusive studies on the effects of $33 \%$ of the pesticides (COFEPRIS 2016).

A cohort study conducted in the USA reports that between 1999 and 2005, urban sprayers used mainly PYR and CAR as active ingredients (Horton et al. 2011). Urban sprayers from the state of Minnesota describe that the most utilized pesticides were herbicides, followed by insecticides and fungicides (Garry et al. 2003). In the state of Nayarit, located in the Mexican Pacific, 18 active ingredients have been reported as employed by urban sprayers from that region; the main chemical groups were PYR, $\mathrm{OP}$, and coumarins, which were used as insecticides, rodenticides, and fungicides (Fuentes et al. 2010).

TABLE III. ACTIVE INGREDIENTS USED BY URBAN PEST CONTROL OPERATORS

\begin{tabular}{llccc}
\hline Active ingredient & Chemical group & Toxicity & Uses & $\begin{array}{c}\text { Frequency } \\
\text { of use (\%) }\end{array}$ \\
\hline Cypermethrin & PIR & II & I, A & 74 \\
Deltamethrin & PIR & III & I & 41 \\
Alphacypermethrin & PIR & II & I, A & 22 \\
Esbiothrin & PIR & II & I, H & 7 \\
Permethrin & PIR & II & I & 4 \\
Pyrethrin & PIR & II & I, A & 4 \\
Chlorpyrifos methyl fosforito & OP & II & I & 26 \\
Dichlorvos & OP & Ib & I, A & 26 \\
Diazinon & OP & II & I, A & 12 \\
Difethialone & Cumarins & Ib & R & 11 \\
Flocoumafen & Cumarins & I & R & 8 \\
Bromadiolone & Cumarins & Ia & R & 7 \\
Propoxur & CAR & II & I & 19 \\
Bendiocarb & CAR & II & I & 8 \\
Fipronil & Phenylpyrazole & II & I & 37 \\
Imidacloprid & Chloronicotinyl & II & I & 33 \\
Amitraz & Amidines & III & A & 15 \\
Aluminum phosphide & Metal phosphide & Ib & I, R & 4 \\
\hline
\end{tabular}

OP: organophosphates, PIR: pyrethroids, CAR: carbamates, Ia: extreme toxicity, Ib: highly hazardous, II: moderately hazardous, III: slightly dangerous. I: insecticide, A: acaricide, R: rodenticide 
Rojas-García et al. (2011) conducted a study on pesticide retailers in Nayarit. The authors found that the most used pesticides were insecticides, herbicides, and fungicides, and the chemical groups were OP, PYR, CAR, and OCP.

Our group observed that urban pest control operators use pesticides: aluminum phosphide (a highly hazardous metallic phosphide), bromadiolone and difethialone (both extremely dangerous coumarins), flocoumafen (a slightly-to-highly toxic coumarin), dichlorvos (a highly toxic OP), and chlorpyrifos (a moderately dangerous OP). These pesticides have been restricted in Mexico and prohibited in other countries. The lack of updating of the Mexican legislation on the use and handling of pesticides results in the use of active ingredients that, due their high toxicity, environmental persistence, and risks to health, have been banned or restricted in other countries (COFEPRIS 2016).

The personal protection equipment (PPE) used by urban pest control operators and the practices in which they engage when handling pesticides are illustrated in table IV. Three out of 10 fumigators do not use full PPE equipment. Only $50 \%$ of urban pest control operators utilized some protective element to handle pesticides, but they left some of their body parts exposed, such as skin, nose, and mouth, which are potential routes of exposure where pesticides may enter the body. These results are in accord with those described for agriculturists (Gomes et al. 1999, Pérez-Herrera et al. 2008, Bradman et al. 2009, Jensen et al 2011, Lekei et al. 2014) and pesticide retailers (Rojas-García et al. 2011). Only a small

TABLE IV. PPE AND HABITS IN HANDLING PESTICIDES

\begin{tabular}{ll}
\hline PPE AND HANDLING PRACTICES & $\%$ \\
\hline PPE & \\
Mask & 70 \\
Hat or cap & 63 \\
Gloves & 59 \\
Eveglasses & 52 \\
Boots & 44 \\
Overalls & 33 \\
Handkerchief & 11 \\
Trousers & 11 \\
Habits in handling pesticides & \\
Uses pesticides only with working clothes & 92 \\
Washes the spraying equipment & 88 \\
Bathes after work & 69 \\
Eats at work & 62 \\
Smokes at work & 35 \\
\hline
\end{tabular}

PPE: personal protection equipment percentage of the workers use full protective gear when handling pesticides. It has been described that influential factors for the non-use of PPE include age, years of experience, lapse of time required to carry out the activity, lack of training, climatic conditions, the high price of PPE, and workers' perception about the risks to their health (Idrovo 2005, Hofmann et al. 2009, Lombardi et al. 2009).

Urban pest control operators perform activities such as washing their spraying devices and eating or smoking during the workday, which increase the risk of exposure. All fumigators have a specific place to store the pesticides in their company's building; however, $23 \%$ have taken pesticides to their homes. Therefore, exposure may continue even after finishing their work. On the other hand, practices such as bathing after the workday and using work-exclusive clothing help reducing the exposure.

Yeary et al. (2009) reported that inadequate work practices led to decreased cholinesterase activity in applicators of fertilizers and herbicides in urban areas. These workers were deemed unable to work until their cholinesterase levels were normal. The Official Mexican Standard NOM-017-STPS-2008 (STPS 2008) states that every worker exposed to any chemical substance must wear PPE to decrease the risk of intoxication and exposure. NOM-256-SSA1-2012 (SSA 2013) establishes the use of overall, boots, work shirt, and gloves when handling pesticides, and it also indicates that workers must change their clothes after fumigations, must never eat or smoke during working hours, and must always bathe after using pesticides.

In order to prevent intoxications and health damage when using pesticides, it is important to observe good practices when handling and applying pesticides (AMIFAC 2005). NOM-017-STPS-2008 (STPS 2008) states that employers must provide PPE, offer constant training, and supervise that workers use their PPE during working hours. It is mandatory for workers to use PPE and participate in trainings on the use and handing of pesticides.

\section{Knowledge of policies related to pesticides}

Table $\mathbf{V}$ presents the information that urban pest control operators must know regarding legal system and norms on pesticides. Two out of 10 fumigators possess some knowledge about the departments in charge of supervising the control and registration of pesticides, while fewer than $10 \%$ are aware of the normativity on workers' health protection and good practices when handling these toxic products. The law establishes that the primary responsibility falls 
TABLE V. KNOWLEDGE OF POLICIES RELATED TO PESTICIDES

\begin{tabular}{lr}
\hline Knowledge of policies related to pesticides & $\%$ \\
\hline Responsible for the analysis of contaminants in the workplace to prevent health damage & 27 \\
Existence of controls for the sale of pesticides & 23 \\
Agency responsible for overseeing the registration and handling & 22 \\
Guidelines about good practices on pesticide residues analyses & 7 \\
Existence of legal systems for the protection of workers' health & 7 \\
Standard pattern obligations of the company to the management of pesticides & 0 \\
Rules contained in pesticides codices & 0 \\
\hline
\end{tabular}

on the establishments' managers and employees; thus, they must coordinate with authorities in order to prevent and control health risks, relying on the most currently issued regulations (DOF 2014).

Article 123 of the Mexican Constitution, in its fractions XIII, XIV, and XV establishes that companies must provide workers with adequate training, and also states they are responsible for the prevention and care of accidents and occupational diseases. The employer is obligated to observe what the law states on environmental safety and health, according to the nature of the business; he must take measures to prevent accidents. Moreover, all establishments that offer spraying services in urban areas must have proper authorization, in concordance with Article 198 of the Ley General de Salud (General Health Law) (DOF 1984).

Legislation on pesticides must be comprehensive, taking into account aspects of labeling, storage, transportation, and elimination of pesticides in order to reduce risks to human health and to the environment. Despite the existence of nationwide regulations, they are not effectively implemented, and the exposed population knows little about them (FAO/OMS 2007).

NOM-256-SSA1-2012 (SSA 2013) establishes the requirements for establishments and individuals working in urban pest control. It also states the responsibilities of the technical manager and pesticide applicators; the requisites for pesticide labeling and health control; good practices during service and the use of disinfectants, and the vigilance of the workers' health.

Regarding knowledge on established policies, $19 \%$ of the fumigators knew about regulations of pesticides and $22 \%$ applied the policies regarding the use of the correct PPE. Despite that $100 \%$ of the fumigators receive training regarding pests, they are not given sufficient information about the products they use. The lack of knowledge about pesticides and the regulations involved in their use may contribute to inadequate handling of pesticide products and an increased risk for the workers' health.

Eleven percent of urban pest control operators have both an administrative position and work as fumigators in the same company. According to article 198 of the Ley General de Salud and NOM-256SSA1-2012 (SSA 2013), a person cannot have an administrative position and use pesticides, because coworkers may be exposed to pesticides if good hygiene practices are not observed.

A study conducted by Matthews et al. (2011) on legislation and regulations on pesticide use in countries with endemic vector-borne diseases, describes the deficiencies of the legal system for controlling the use of pesticides among member states and regions of the World Health Organization.

The ability to regulate the use of pesticides for public health purposes is weak because there is a lack of constant supervision by institutions in charge. As a result, the health of workers and general population may be compromised.

\section{Activity of BuChE}

The activity of the BuChE is an exposure biomarker of pesticides, as stipulated in NOM-047SSA1-2011 (SSA 2012). In this work, BuChE activity in serum was determined in the 27 urban pest control operators, and then it was compared with 26 non-occupationally exposed subjects. Table VI presents the BuChE values of the study population. The mean value of $\mathrm{BuChE}$ for both the exposed and non-exposed group was found to be within the reference range. The reference group (non-occupationally exposed) was mainly composed by workers of the Autonomous University of Yucatan. We did not find significant differences between the BuChE activity on fumigators vs. the non-exposed group $(p=0.26)$. The main mechanism of action of OP and CAR pesticides is the inhibition of cholinesterases; thus, the activity of such enzymes is a classical biomarker of recent exposure of both groups. Many studies have 
TABLE VI. BuChE ACTIVITY IN THE STUDY POPULATION

\begin{tabular}{lcccc}
\hline Parameter & $\begin{array}{c}\text { Urban pest control operators } \\
(\text { arithmetic mean } \pm \text { SD) } \\
\mathrm{n}=27\end{array}$ & $\begin{array}{c}\text { Non-occupationally exposed } \\
(\text { arithmetic mean } \pm \text { SD) } \\
\mathrm{n}=26\end{array}$ & $\mathrm{p}^{\mathrm{a}}$ & Reference values \\
\hline $\mathrm{BuChE}(\mathrm{U} / \mathrm{L})$ & $9,863.79 \pm 1,816.33$ & $10,405.56 \pm 1,591.24$ & 0.264 & $5,320-12,920$ \\
\hline
\end{tabular}

${ }^{a}$ According to the Student-test

evaluated $\mathrm{BuChE}$ and acetylcholinesterase (AChE) as biomarkers of exposure to OP and CAR pesticides in farmers and intoxicated individuals, but little is known about the exposure of urban pest control operators (Hofmann et al. 2010, Araoud et al. 2011, Rojas-García et al. 2011, Contreras et al. 2013).

In our study, fumigators utilized the same pattern of pesticides all year long. Yeary et al. (2009) conducted a cohort study on 150 urban pesticide applicators from Canada. BuChE activity was lower during the summer, when the frequency of pesticides use is higher. Our results are in agreement with those reported by Fuentes et al. (2010), who surveyed AChE activity in 20 urban sprayers hired to control vectors, whose exposure to pesticides fell within the normal reference range.

According to our questionnaire, the use of $\mathrm{OP}$ and CAR pesticides by these workers is low $(26 \%$ and $19 \%$, respectively), which may be the reason for not having noticed a difference in the BuChE activity between groups, in addition to the wide reference value of this enzyme in the population and the rapid recovery of the activity of BuChE within a few days of being decreased. NOM-047-SSA1-2011 (SSA 2012) states that workers exposed to pesticides must monitor their cholinesterase activity at least once a year in order to know their health status. However, since OP and CAR are the only pesticides that inhibit cholinesterases, this Mexican Standard may be obsolete as it does not reflect the magnitude of exposure to different pesticides in use. So, it is suggested to carry out a complete health surveillance of these workers, since there are no biomarkers of exposure to a mixture of pesticides different to OP and CAR.

\section{CONCLUSIONS}

This is the first work that presents the scenario of urban pest control operators' occupational exposure to pesticides, as well as their working conditions, knowledge regarding the application of urban pesticides, and handling-related policies in southeastern Mexico. The urban pest control operators depicted in this study are working in a risk conditions and are exposed to a mixture of active ingredients employed as pesticides. We consider that the health surveillance of these workers should include a full medical examination that comprises other biomarkers besides cholinesterase, which only reflects exposure to OP and CAR. Moreover, normativity on pesticide handling requires updating and fumigators must be educated on policies and regulations regarding the management of pesticides, and trained in health and environmental risks.

\section{ACKNOWLEDGMENTS}

Authors express their gratitude to the Red Temática de Toxicología de Plaguicidas (CONACyT-262284/280045/294303) and to the contributors to this study.

This study was financed by the PROMEP-SEP.

\section{REFERENCES}

Albert L. (2004). Toxicología ambiental. Universidad Autónoma de Ciudad Juárez, Chihuahua, Mexico, p. 453.

Aldana M., Mendívil C., Mada D., Silveira M. and Navarro J. (2003). Alteraciones en el análisis del líquido seminal de aplicadores de insecticidas en el medio urbano. Acta Médica de Sonora 4(4), 5-7.

AMIFAC. (2005). Manual de almacenes de plaguicidas. Asociación Mexicana de la Industria Fitosanitaria, México.

Araoud M., Neffeti F., Douki W., Hfaiedh H.B., Akrout M., Najjar M.F. and Kenani A. (2011). Factors influencing plasma butyrylcholinesterase activity in agricultural workers. Ann. Biol. Clin. 69(2), 159-166. DOI: 10.1684/abc.2011.0531

Arcury T.A., Quandt S.A. and Russell G.B. (2002). Pesticide safety among farmworkers: perceived risk and perceived control as factors reflecting environmental justice. Environ. Health Perspect. 110, 233-239. 
Bradman A., Salvatore A.L., Boeniger M., Castorina R., Snyder J., Barr D.B., Jewell N.P., Kavanagh-Baird G., Striley C. and Eskenazi B. (2009). Communitybased intervention to reduce pesticide exposure to farmworkers and potential take-home exposure to their families. J. Exp. Sci. Environ. Epidemiol. 19, 79-89. DOI: $10.1038 /$ jes.2008.18

COFEPRIS (2016). Catálogo oficial de plaguicidas. Comisión Federal para la Protección contra Riesgos Sanitarios, Mexico. [on line]. http://www.cofepris.gob. $\mathrm{mx} / \mathrm{AZ} /$ Paginas/Plaguicidas\%20y\%20Fertilizantes/ CatalogoPlaguicidas.asp.

Contreras L., Gómez-Pérez R., Rojas G., Cruz I., Berrueta L., Salmen S., Colmenares M., Barreto S., Balza A., Zavala L., Morales Y., Molina Y., Valeri L., Contreras C. and Osuna J. (2013). Occupational exposure to organophosphate and carbamate pesticides affects sperm chromatin integrity and reproductive hormone levels among Venezuelan farm workers. J. Occup. Health 55, 195-203. DOI: 10.1539/joh.12-0144-FS

Cortinas C. (2004). Situación en México de las existencias de plaguicidas sujetos al Convenio de Estocolmo. [on line]. http://siscop.ine.gob.mx/descargas/diagnos/ diag_situacion_plaguicidas_convenio_estocolmo.pdf.

DOF (1984). Ley Federal de Salud. Diario Oficial de la Federación. Mexico, February 7. [on line]. http:// www.diputados.gob.mx/LeyesBiblio/ref/lgs/LGS_ orig_07feb84_ima.pdf.

DOF (2014). Reglamento Federal de Seguridad y Salud en el Trabajo. Diario Oficial de la Federación. Mexico, November 13. [on line]. http://www.diputados.gob.mx/ LeyesBiblio/regla/n152.pdf

Eddleston M., Karalliedde L., Buckley N., Fernando R., Hutchinson G. and Isbister G. (2002). Pesticide poisoning in the developing world - a minimum pesticide list. Lancet 360, 1163-1167. DOI: $10.1016 / \mathrm{S} 0140-6736(02) 11204-9$

FAO/OMS (2007). Primera sesión de la Reunión sobre Gestión de los Plaguicidas y tercera sesión del Panel de Expertos sobre Gestión de los Plaguicidas. Rome, Italy. [on line]. www.fao.org/ag/agp/agpp/pesticid/ manage/htp.htm.

FDA (2009). Rules and regulations governing the licensing of urban pest operators, certification of urban pest applicators and training of technicians and workers, and for other purposes. Department of Health, Food and Drug Administration, Republic of the Philippines. [on line]. https://www.facebook.com/filipinopestcontroltechniciansactiongroup/photos/a.18607554974952 $06.1073741829 .1662162150687876 / 1860761904161$ 232/?type $=3 \&$ theater.

Fuentes M., Medina I., Robledo L., Ostrosky P., Sordo M., Girón P., Lara M., Bermúdez D. and Rojas A.E. (2010).
Determinación de la actividad de acetilcolinesterasa y de la expresión génica en fumigadores urbanos de Nayarit, México. Memorias del VIII Congreso Nacional de la Sociedad Mexicana de Toxicología. Ciudad Obregón, Sonora, Mexico.

Garry V., Holland S., Erickson L. and Burroughs B. (2003). Male reproductive hormones and thyroid function in pesticide applicators in the Red River Valley of Minnesota. J. Toxicol. Environ. Health A 66(11), 965-986. DOI: $10.1080 / 15287390390212792$

Gomes J., Lloyd O.L., AND Revitt D.M. (1999). The influence of personal protection, environmental hygiene and exposure to pesticides on the health of immigrant farm workers in a desert country. Int. Arch. Occup. Environ. Health 72, 40-45. DOI: 10.1007/s004200050332

González Arias C., Robledo Marenco M., Medina Díaz I., Velázquez Fernández J., Girón Pérez M. and Quintanilla Vega B. (2010). Patrón de uso y venta de plaguicidas en Nayarit, México. Rev. Int. Contam. Ambie. 26, 221-228.

González L. and Alvarado J. (1996). Efectos tóxicos de los plaguicidas agrícolas en el estado de Yucatán. In: La toxicología en México. Estado actual y perspectivas (Albert L.A. and Saldívar L., Ed.). Sociedad Mexicana de Toxicología, Xalapa, Mexico.

González N.R. and Alvarado M.J. (2008). Efectos tóxicos de los productos agrícolas en el estado de Yucatán. Unidad de Ciencias Sociales, CIR "Dr. Hideyo Noguchi", Mérida, Mexico.

Hines C.J. and Deddens J.A. (2001). Determinants of chlorpyrifos exposures and urinary 3, 5, 6-trichloro2-pyridinol levels among termiticide applicators. Ann. Occup. Hyg. 45(4), 309-321. DOI: $10.1016 / \mathrm{S} 0003-4878(01) 00026-6$

Hofmann J.N., Keifer M.C. and Furlong C.E. (2009). Serum cholinesterase inhibition in relation to paraoxonase-1 (PON1) status among organophosphate-exposed agricultural pesticides handlers. Environ. Health Perspect. 117, 1402-1408. DOI: 10.1289/ehp.0900682

Horton M.K., Jacobson J.B., McKelvey W., Holmes D., Fincher B., Quantano A. and Whyatt R.M. (2011). Characterization of residential pest control products used in inner city communities in New York City. J. Exp. Sci. Environ. Epidemiol. 21(3), 291-301.

DOI: $10.1038 /$ jes.2010.18

Idrovo Á.J. (2005). Hacia una salud pública pluralista: el caso de los plaguicidas y la salud humana. Rev. Salud Pública 7(3), 349-359.

INEGI (2016). Monografías climatológicas sobre el territorio de Yucatán. Instituto Nacional de Estadística y Geografía, Mexico. [on line]. http://cuentame.inegi. org.mx/monografias/informacion/yuc/territorio/clima. aspx. 
INIFAP (2011). Instituto Nacional de Investigaciones Forestales, Agrícolas y Pecuarias. [en línea]. http:// www.inifap.gob.mx/revistas/ciencia_agricola/volesp_ num1_2011.pdf.

INSP. (2013). Encuesta Nacional de Salud y Nutrición 2012. Resultados por entidad federativa, Yucatán. Instituto Nacional de Salud Pública, Mexico. [on line]. Disponible en: (https://encuestas.insp.mx).

Jensen H.K., Konradsen F., Jors E., Petersen J.H. and Dalsgaard A. (2011). Pesticide use and self-reported symptoms of acute pesticide poisoning among aquatic farmers in Phnom Penh, Cambodia. J. Toxicol. DOI: $10.1155 / 2011 / 639814$

Kamijima M., Hibi H., Gotoh M., Taki K., Saito I., Wang H., Itohara S., Yamada T., Ichihara G., Shibata E., Nakajima T. and Takeuchi Y. (2004). A survey of semen indices in insecticide sprayers. J. Occup. Health 46, 109-118.

Lekei E.E., Ngowi A.V. and London L. (2014). Farmers' knowledge, practices and injuries associated with pesticide exposure in rural farming villages in Tanzania. BMC Public Health 14: 389.

DOI: $10.1186 / 1471-2458-14-389$

Lombardi D.A., Verma S.K., Brennan M.J. and Perry M.J. (2009). Factors influencing worker use of personal protective eyewear. Accident Anal. Prev. 41(4), 755762. DOI: 10.1016/j.aap.2009.03.017

Matthews G., Zaim M., Yadav R.S., Soares A., Hii J., Ameneshewa B. and van den Berg H. (2011). Status of legislation and regulatory control of Public Health pesticides in countries endemic with or at risk of major vector-borne diseases. Environ. Health Persp. 119(11), 1517-1522. DOI: 10.1289/ehp.1103637

Mendívil G.C., Mada G.C., Aldana M.L., Silveira G.M., Navarro H.J., Reyes B.L. and Gonzales E. (2004). Análisis de líquido seminal y cuantificación de plaguicidas en trabajadores de control de plagas en Hermosillo, Sonora. Memorias del VI Congreso Nacional de la Sociedad Mexicana de Toxicología. Guadalajara, Jalisco, Mexico.

Mostafalou S. and Abdollahi M. (2017). Pesticides: an update of human exposure and toxicity. Arch. Toxicol. 91(2), 549-599. DOI:10.1007/s00204-016-1849-x

OMS (1990). Plaguicidas. Informe Técnico No. 12. Organización Mundial de la Salud, Ginebra, Suiza. [on line]. http://www.senasa.go.cr/senasa/sitio/ files/080312055137.pdf.

Pérez-Herrera N., Polanco-Minaya H., Salazar-Arredondo E., Solís-Heredia M., Hernández-Ochoa I., Rojas-
García E., Alvarado-Mejía J., Borja-Aburto V. and Quintanilla-Vega B. (2008). PON1Q192R genetic polymorphism modifies organophosphorous pesticide effects on semen quality and DNA integrity in agricultural workers from southern Mexico. Toxicol. Appl. Pharmacol. 230, 261-268. DOI: $10.1016 /$ j.taap.2008.02.021

Rojas-García A.E., Medina-Díaz I.M., de Lourdes Robledo-Marenco M., Barrón-Vivanco B.S., Girón-Pérez M.I., Velázquez-Fernández J.B., González-Árias C., Albores-Medina A., Quintanilla-Vega B., OstroskyWegman P., Rojas-García M., Pérez-Herrera N. and López-Flores F. (2011). Hematological, biochemical effects, and self-reported symptoms in pesticide retailers. J. Occup. Environ. Med. 53(5), 517-521.

DOI: 10.1097/JOM.0b013e318215fbf2

Romero Lankao P. (1999). La política ambiental ante los diversos retos de la sustentabilidad. Gestión y Política Pública 8(2), 301-321.

Silveira M.I., Amarillas V., Rodríguez G. and Aldana M. (2011). Valoración del riesgo de exposición a insecticidas organofosforados en adultos del sexo masculino en Sonora, México.Ciencia@uaq 4(2),70-81.

SSA (2012). Norma Oficial Mexicana NOM-047SSA1-2011. Salud ambiental. Índices biológicos de exposición para el personal ocupacionalmente expuesto a sustancias químicas. Secretaría de Salud. Diario Oficial de la Federación. Mexico, June 6.

SSA (2013). Norma Oficial Mexicana NOM-256SSA1-2012. Condiciones sanitarias que deben cumplir los establecimientos y personal dedicados a los servicios urbanos de control de plagas mediante plaguicidas. Secretaría de Salud. Diario Oficial de la Federación. Mexico, January 29.

SSA (2015). Panorama epidemiológico de fiebre por dengue y fiebre hemorrágica por dengue. [on line]. http:// www.epidemiologia.salud.gob.mx/dgae/panodengue/ intd_dengue.htm.

STPS (2008). Norma Oficial Mexicana NOM-017STPS-2008. Equipo de protección personal-Selección, uso y manejo en los centros de trabajo. Secretaría del Trabajo y Previsión Social. Diario Oficial de la Federación. Mexico, December 9.

Yeary R., Eaton J., Gilmore E., North B. and Singell J. (2009). A multiyear study of blood cholinesterase activity in urban pesticide applicators. J. Toxicol. Environ. Health. 39(1):11-25. DOI: $10.1080 / 15287399309531733$ 